\title{
Relationship between personality and attitudes to Wikipedia
}

\author{
Bartosz Atroszko \\ Faculty of Social Science \\ University of Gdansk \\ Gdansk, Poland \\ bartosz.atroszko@gmail.com
}

\author{
Piotr Bereznowski \\ Faculty of Social Science \\ University of Gdansk \\ Gdansk, Poland \\ piotr.bereznowski@gmail.com
}

\author{
Wiktor Kornel Wróbel \\ Faculty of Social Science \\ University of Gdansk \\ Gdansk, Poland \\ w.kornel.wrobel@gmail.com
}

\author{
Paweł Atroszko \\ Faculty of Social Science \\ University of Gdańsk \\ Gdansk, Poland \\ pawel.atroszko@gmail.com
}

\begin{abstract}
The aim of the study was to examine the relationship between attitudes to Wikipedia and six personality traits (extraversion, emotional stability, openness to experience, conscientiousness, agreeableness and cynical hostility) among Polish students. Conscientiousness was negatively related to editing Wikipedia and positive opinions about Wikipedia. Cynical hostility was not related to any specific attitude to Wikipedia. Extraversion and openness to experience were positively related to positive opinions on Wikipedia. The results are inconsistent with previous work and future studies should clarify the divergences.
\end{abstract}

Keywords- Open Educational Resources, cynical hotility, knowledge sharing, five factor model, Wikipedia, Big Five personality traits

\section{INTRODUCTION}

Constant growth of Internet network has an influence over immense part of human lives and is responsible for lots of macrosocial changes in past decades. Web allows communication, looking for information, shopping, watching television, reading newspapers and even voting. Publishers following general trend decided to create online encyclopaedias available to use in exchange for payments. Created by users for users Wikipedia was launched as free alternative. Currently it is placed as the seventh most popular website and the source of information for millions of users of the Internet. In light of these facts, it is important to define the specific personality traits of supporters and opponents of Wikipedia and their attitude towards Wikipedia and other forms of knowledge.

Wikipedia is a multilingual, Internet encyclopaedia created based on free-content, this means that any Internet user can potentially edit any available article. Wikipedia is one of the most widely used sources of information with 475 million unique visitors per month. Study reports that approximately $88 \%$ of all students use Wikipedia as a part of their university studies [1]. The most essential assets of Wikipedia are: 1) availability (is available around the clock for all Internet users), 2) free of charge (no payments are required to use it), 3) topicality (every day new articles are being made and existing ones are constantly updated). Wikipedia is not a commercial project, contains no advertising and is maintained by voluntary donations of private individuals. Promotion and support of polish version of Wikipedia is done by the Association Wikimedia Poland, whereas Wikipedia is a project of non- profit organisation Wikimedia Foundation. What is worth noting is that the Association Wikimedia Poland is a founding member of the Coalition for Open Education, which implies that Wikipedia should be treated as Open Education Resources (OER) repository [2]. Open Education Resources are being defined as "teaching, learning and research materials in any medium, digital or otherwise, that reside in the public domain or have been released under an open license that permits nocost access, use, adaptation and redistribution by others with no or limited restrictions" [3]. OER are the practical realisation of an "open education idea build on a believe that whole world knowledge is a public good, thus everybody should have freedom of using, adjusting to one's needs, advancing and spreading educational materials without restraints to make education more accessible as well as more effective" [2]. Previous studies on Wikipedia showed that men are more likely to use Wikipedia than women and are less critical towards its content [1][4]. Furthermore, students in Engineering, Computer, Maths or general science fields are more likely to use Wikipedia than those on Humanistic, Social Science and Education [1][5]. Moreover, a substantial difference in usefulness of Wikipedia was observed as $78.2 \%$ of participants studying Engineering, Computer Science \& Maths subjects reported Wikipedia as useful, whereas only $34.4 \%$ of studying Education course [1]. This difference is probably due to Educational studies requiring from students deep research on the subject when writing theses, citing authors directly and using reliable sources, whereas Wikipedia is seen as not "scientific enough". Wikipedia may be seen by many as knowledge sharing. Studies showed relationship between knowledge sharing and Big Five personality traits. Analogically attitudes to Wikipedia should be linked with character traits. One especially interesting personality trait, recently increasingly researched is cynical hostility.

Cynical hostility, defined as an enduring, negative attitude towards others including cognitive, affective, and behavioural components, has progressively been established as a psychological characteristic with a negative impact on health, and recently its potential role is starting to be recognized in educational studies [6]. Cynical hostility is comprised of three components: cynicism, mistrust and hostile attributional style [7]. Hostile person believes that others are motivated by selfish concerns (cynicism), expects that people are frequent source of mistreatment (mistrust) and interprets others' actions as involving aggressive intent (hostile attributional style). One of 
the main goals of the hostile person is to retain one's own resources. This tendency can be observed in students in motivational aspects of cognition, such as striving for power and achievements [8]. There is also strong evidence supporting claim that cynical hostility is negatively related to social support and health [7]. Furthermore, cynical hostility is positively related to loneliness, anxiety and depressiveness [9]. Cynically hostile individuals report engagement in larger number of conflicts and experiencing higher levels of stress both objectively and subjectively measured. Recent study showed that relationship between cynical hostility and stress is fully mediated by ineffective coping strategies, congruent with the hostile attitude [10]. It can be expected that the basic lack of trust and belief that everyone is motivated solely by selfinterest related to cynical hostility is negatively related to editing articles on Wikipedia, positive opinions and attitude to Wikipedia, as well as trust in it.

Concept of personality proposed in five factor model suggests that human personality can be described on five dimensions: openness to experience, conscientiousness, extroversion, agreeableness and emotional stability [11]. Extraversion is recounted as talkativeness, assertiveness and tendency to seek stimulation which is especially interesting in regard to using and co-creating Wikipedia which can provide plethora of stimuli. Conscientiousness defined as habit to be organized and self-disciplined as well as preferring planned over spontaneous behaviour is positively related to academic grades and mindfulness [12][13], and also shows negative relationship with many disorders, anxiety and depressiveness [14]. Conscientiousness may be a factor contributing to greater involvement in editing articles in Wikipedia because it requires self-discipline and organization skills to perform this task systematically. On the other hand it may also be related to less positive attitudes and trust to Wikipedia. Those who are highly conscientious may be willing to invest more effort in studying direct resources, especially scientific, and rely more on their own judgement than on summaries of topics prepared for Wikipedia. Emotional stability described as tendency to not experiencing unpleasant emotions easily, is negatively connected with many disorders, anxiety as well as depressiveness, and shows positive relationship with mindfulness and academic satisfaction [15]. It can be predicted that more emotionally stable individuals may more frequently engage in systematic editing of articles in Wikipedia because it is a task that requires balanced effort and judgement. Agreeableness is linked to being cooperative [16], altruistic, building community and sharing. Openness to experience is a trait connected with expertise, curiosity, seeking answers and ascertaining oneself. Studies show that knowledge sharing is related to personality traits, especially three of them: openness to experience, conscientiousness and agreeableness, which explain $27 \%$ of the variance in knowledge sharing [17]. However, these results were obtained on people sharing knowledge inside a company and should be seen as far less public way of sharing knowledge than Wikipedia is. Wikipedia is heavily criticised and less trusted, than other sources of information due to people believing that it has a lot of misinformation [18]. Therefore, traits that are commonly contributed to sharing knowledge may be altered due to different standards regarding usage and contribution to shared knowledge on Wikipedia. Nonetheless, it seems reasonable to claim that personality traits are related to frequency of usage of Internet [19], ways of browsing web and types of visited websites, but further research is needed. Taking that into account it can be predicted that extroverts and those who are open to experience and agreeable may be the most trusting in Wikipedia and having most positive attitude to it.

\section{HYPOTHESIS}

H1: Agreeableness, Openness to Experiences, Emotional Stability, Conscientiousness are positively related to editing articles on Wikipedia, while cynical hostility is negatively related to editing articles on Wikipedia.

H2: Cynical hostility is negatively related to positive opinions and attitude to Wikipedia, as well as trust in it.

H3: Openness to experience, Agreeableness and Extraversion are positively related to positive opinions on Wikipedia and trust in it.

H4: Conscientiousness is negatively related to positive opinions on Wikipedia and trust in it.

\section{METHODS}

Participants. Two hundred six students took part in this study: 183 women $(89 \%)$ and 23 men $(11 \%)$. Their mean age was $M=21.50$ years $(S D=3.22)$. Four people did not report their age. The majority of respondents (149 people, $72 \%$ ) were residents of a city, 55 people $(27 \%)$ reported countryside as a place of residence and two people did not report where they live (1\%). Two hundred six students were enrolled at 210 courses of study, because five people studied at two faculties. One person did not report field of study. One individual studied full time and part time simultaneously.

All respondents were students of the University of Gdansk. One hundred and ninety eight individuals have studied at the Faculty of Social Sciences. Eight people have studied at other faculties of the University of Gdansk, but during the survey participated in optional classes at the Faculty of Social Sciences. Almost half of the respondents were students of pedagogics, because as representatives of the future staff of schools and educational institutions their opinions are the most interesting for researchers. Their attitude towards Wikipedia may have an impact on their behaviour in future work with students and pupils using Wikipedia as a source of information.

Measures. Personality traits were measured with Ten Item Personality Traits (TIPI) [20], a 10-item self-report measure with 7-point Likert response scale which showed good validity and test-retest reliability in previous research [21]. It contains 5 subscales: openness to experience, conscientiousness, extroversion, agreeableness and neuroticism. High score on each subscale reflects high score on certain dimension except emotional stability. For the present sample the SpearmanBrown coefficients were equal 0.41 for openness to experience, 0.55 for agreeableness, 0.60 for extraversion, 0.63 for emotional stability and 0.76 for conscientiousness.

Cynical hostility was measured by Cook Medley Hostility Inventory Brief, developed on the basis of five items from Cook-Medley Hostility Inventory [22]. It is a tool widely used 
in large scale surveys concerning health and psychosocial functioning. The response alternatives range from completely disagree (1) to completely agree (6). It showed good validity and reliability in previous studies [23]. For the present sample the Cronbach's alpha reliability coefficient was 0.70 .

Attitudes toward Wikipedia were measured by original questionnaire [18] which comprises 12 various statements about Wikipedia measured with 5-point Likert response scale, one question about frequency of usage, one question about editing Wikipedia's sites and one question about preferences between Wikipedia and traditional (paper) encyclopaedia. Furthermore, participants were asked to evaluate trustworthiness of television, radio, press, encyclopaedia PWN (Polish Scientific Publishers PWN) and Wikipedia. The response alternatives range from in general are not trustworthy (1) to are fully trustworthy (10).

Procedure. Data collection used convenience sampling. The survey was conducted from 25 May to 31 May 2015 at the Faculty of Social Sciences of the University of Gdansk. Students were invited to participate anonymously in the study during lectures or classes. More the $90 \%$ of all present students agreed to do so. Participation in the study was anonymous and no monetary or other material rewards were offered.

Statistical analyses. Means, standard deviations, percentages and correlation coefficients were calculated. Exploratory factor analysis was conducted in order to explore factors related to attitudes to Wikipedia on the basis of 12 questions regarding attitudes to Wikipedia. Hierarchical regression analyses were conducted. All tests were two-tailed, and the significance level was set to $\alpha=0.05$. Dependent variables were: believe that Wikipedia is valuable, believe that Wikipedia is detrimental and believe that Wikipedia is biased. Age and sex were added in the first step as independent variables. In the second step Big Five personality traits were added. Step three included cynical hostility. All statistical analyses were conducted in IBM SPSS 23.

\section{RESULTS}

\section{A. Correlation coefficients}

Extroversion was positively related to the opinion that Wikipedia is valuable, needed $(r=0.14 ; p=0.04)$. Openness to experience was positively associated with the opinion that there is a lot of misinformation in Wikipedia $(r=0.16 ; p=0.03)$, as well as with the opinion that for the most part the contents of Wikipedia are reliable $(r=0.16 ; p=0.02)$. Conscientiousness was negatively linked to the opinion that Wikipedia is valuable, needed $(r=-0.17 ; p=0.01)$ and to the opinion that young people can expand their horizons and gain new knowledge through Wikipedia $(r=-0.15 ; p=0.03)$ (Tab. I).
TABLE I. SPEARMAN'S RANK CORRELATION COEFFICIENTS OF PARTICULAR PERSONALITY TRAITS AND ACCEPTANCE OF 12 OPINIONS ON WIKIPEDIA

\begin{tabular}{lccccccc}
\hline Variable & $M d m$ & \multicolumn{1}{c}{$\mathrm{E}$} & \multicolumn{1}{c}{$\mathrm{A}$} & \multicolumn{1}{c}{$\mathrm{C}$} & $\mathrm{ES}$ & $\mathrm{OE}$ & \multicolumn{1}{c}{$\mathrm{CH}$} \\
\hline O-1 & 4 & $0.14^{*}$ & 0.02 & $-0.17^{*}$ & -0.08 & 0.05 & -0.05 \\
O-2 & 4 & -0.12 & 0.05 & 0.10 & -0.08 & -0.09 & 0.05 \\
O-3 & 4 & 0.09 & -0.04 & -0.09 & -0.11 & 0.13 & -0.03 \\
O-4 & 4 & 0.04 & 0.01 & -0.12 & -0.07 & $0.16^{*}$ & 0.05 \\
O-5 & 3 & -0.04 & 0.01 & 0.06 & 0.03 & $0.16^{*}$ & -0.01 \\
O-6 & 3 & 0.02 & 0.00 & 0.10 & -0.02 & 0.00 & 0.04 \\
O-7 & 4 & 0.10 & 0.11 & -0.03 & -0.03 & 0.05 & -0.03 \\
O-8 & 3 & 0.00 & -0.09 & 0.05 & 0.02 & 0.00 & 0.05 \\
O-9 & 2 & -0.13 & -0.03 & -0.02 & -0.02 & -0.07 & 0.01 \\
O-10 & 3 & -0.04 & 0.02 & -0.00 & -0.04 & -0.05 & -0.09 \\
O-11 & 4 & 0.11 & 0.02 & $-0.15^{*}$ & -0.05 & 0.13 & 0.02 \\
O-12 & 3 & 0.04 & -0.13 & 0.05 & -0.02 & 0.02 & 0.09 \\
\hline$N o t e$ & - & & & &
\end{tabular}

Note. E - Extroversion, A - Agreeableness, C - Conscientiousness, ES Emotional Stability, OE - Openness to Experience, $\mathrm{CH}$ - Cynical Hostility, O-1 - I believe that Wikipedia is valuable, needed, $\mathrm{O}-2$ - I believe that encyclopaedias should only be created by experts, O-3 - Wikipedia is increasing people's access to knowledge and information, O-4 - There is a lot of misinformation in Wikipedia, 0-5 - For the most part the contents of Wikipedia are reliable, O-6 - Information contained in Wikipedia is constantly updated, 0-7 - Wikipedia is a useful teaching aid for pupils and students, O-8 - Information in Wikipedia is presented in a biased manner, articles express the opinions of specific editors, O-9 - Using Wikipedia by pupils and students has a detrimental effect on them, O-10 - Because of Wikipedia there is more plagiarism in schools and at universities, $\mathrm{O}-11$ Young people can expand their horizons and gain new knowledge through Wikipedia, O-12 - In Wikipedia you can find information not available in other sources.

$* p<0.05 ; * * p<0.01$.

Conscientiousness was positively related to trust in television $(r=0.15 ; p=0.03)$. Furthermore, cynical hostility was negatively associated with trust in encyclopaedia PWN $(r$ $=-0.20 ; p<0.01)$ and in press $(r=-0.27 ; p<0.01)$. Editing Wikipedia $(0-n o, 1-y e s)$, which means creating new articles or changing existing articles, was negatively linked to conscientiousness $(r=-0.15 ; p=0.03)$ (Tab. II).

TABLE II. PEARSON'S CORRELATION COEFFICIENTS OF LEVEL OF TRUST IN CORRECTNESS OF INFORMATION IN PWN ENCYCLOPAEDIA, WIKIPEDIA, RADIO, PRESS, TELEVISION AND PARTICULAR PERSONALITY TRAITS

\begin{tabular}{lccccccc}
\hline Variable & $M(S D) / \%$ & $\mathrm{E}$ & $\mathrm{A}$ & $\mathrm{C}$ & $\mathrm{ES}$ & $\mathrm{OE}$ & $\mathrm{CH}$ \\
\hline PWN & $8.91(1.38)$ & 0.07 & 0.10 & 0.04 & 0.08 & 0.02 & $-0.20^{* *}$ \\
Wikipedia & $5.75(1.66)$ & 0.13 & 0.07 & -0.02 & -0.08 & 0.03 & -0.02 \\
Radio & $5.47(2.18)$ & 0.08 & 0.10 & 0.13 & 0.03 & -0.05 & -0.13 \\
Press & $5.15(2.07)$ & 0.08 & 0.08 & 0.09 & 0.11 & -0.03 & $-0.27^{* *}$ \\
Television & $4.50(2.22)$ & 0.09 & 0.12 & $0.15^{*}$ & 0.03 & -0.08 & -0.13 \\
EWA & $5.3 \%$ yes & -0.03 & 0.02 & $-0.15^{*}$ & -0.11 & 0.10 & -0.02 \\
\hline
\end{tabular}

Note. E - Extroversion, A - Agreeableness, C - Conscientiousness, ES Emotional Stability, OE - Openness to Experience, $\mathrm{CH}$ - Cynical Hostility, EWA - Editing Wikipedia articles $(0-n o, 1-y e s)$. 
$* p<0.05 ; * * p<0.01$

Using traditional, printed on paper encyclopaedia (1 More often I use Wikipedia, 2 - I use Wikipedia as often as printed encyclopaedia, 3 - More often I use printed encyclopaedia) was linked to emotional stability $(r=0.20 ; p<$ 0.01) (Tab. III).

TABLE III. SPEARMAN'S RANK CORRELATION COEFFICIENTS OF FREQUENCY OF USING WIKIPEDIA AND PRINTED ENCYCLOPAEDIA WITH PARTICULAR PERSONALITY TRAITS

\begin{tabular}{lcccccc}
\hline Variable & $\mathrm{E}$ & $\mathrm{A}$ & $\mathrm{C}$ & $\mathrm{ES}$ & $\mathrm{OE}$ & $\mathrm{CH}$ \\
\hline FUW & 0.14 & -0.02 & -0.02 & -0.05 & 0.06 & 0.04 \\
UPE & -0.04 & -0.06 & 0.10 & $0.20^{* *}$ & 0.04 & -0.11 \\
\hline
\end{tabular}

Note. E - Extroversion, A - Agreeableness, C - Conscientiousness, ES Emotional Stability, OE - Openness to Experience, $\mathrm{CH}$ - Cynical Hostility, FUW - Frequency of using Wikipedia (1 - Never, 2 - Once a week or less, 3 - Few times a week, 4 - Everyday), UPE - Using printed encyclopaedia (1 More often I use Wikipedia, 2 - I use Wikipedia as often as printed encyclopaedia, 3 - More often I use printed encyclopaedia).

$* p<0.05 ; * * p<0.01$.

\section{B. Exploratory factor analysis}

Exploratory factor analysis was conducted in order to explore factors related to attitudes to Wikipedia on the basis of 12 questions regarding attitudes to Wikipedia. In order to determine the optimal number of factors to retain Kaiser's eigenvalue-greater-than-one rule was applied. In order to permit correlations among factors, an oblique rotation, promax rotation with Kappa equal four, was used. The results showed three factors which explained in total $53.54 \%$ of the variance of the scores. On the basis of analysis of the content of items loading on particular factors these factors were named accordingly Belief, that Wikipedia is valuable (items with loadings greater than 0.40: 3 (0.87), $1(0.86), 11(0.81), 7$ $(0.80), 5(0.53), 6(0.41)$; explains $31.25 \%$ of the variance), Belief, that Wikipedia is detrimental (items: $10(0.76), 4(0.70)$, 2 (0.51), 9 (0.41); explains $12.52 \%$ of the variance) and Belief, that Wikipedia is biased (items with loadings greater than 0.40: 8 (0.70), 12 (0.66); explains $9.77 \%$ of the variance). Factors 1 and 2 were correlated negatively, $\mathrm{r}=-0.34$, while there were no other significant correlations between factors. Three variables representing these factors were created using Bartlett's method. These variables were then used in regression analyses.

\section{Regression analyses}

The regression analysis for belief that Wikipedia is valuable showed that the independent variables added in step 1 explained $2.5 \%$ of the variance $\left(F_{2,178}=2.28, p=0.11\right)$. The independent variables added in step 2 explained additional $2.5 \%$ of the variance $\left(F_{5,173}=0.89, p=0.49\right)$. The independent variables added in step 3 explained additional $0,2 \%$ of the variance $\left(F_{1,172}=0.45, p=0.50\right)$. The independent variables explained a total of $5.2 \%$ of the variance $\left(F_{8,172}=1.18, p=\right.$ $0.31)$. Significant variable in step 3 was sex, showing that men score higher on belief that Wikipedia is valuable (Tab. IV).

The regression analysis for belief that Wikipedia is valuable showed that the independent variables added in step 1 explained $0.2 \%$ of the variance $\left(F_{2,178}=0.18, p=0.84\right)$. The independent variables added in step 2 explained additional $0.8 \%$ of the variance $\left(F_{1,172}=0.14, p=0.71\right)$. The independent variables added in step 3 explained additional $0.1 \%$ of the variance $\left(F_{1,172}=0.45, p=0.50\right)$. The independent variables explained a total of $1.0 \%$ of the variance $\left(F_{8,172}=0.23, p=\right.$ 0.99). There were no significant variables added in step 3 (Tab. IV).

TABLE IV. HIERARCHICAL REGRESSION ANALYSES

\begin{tabular}{|c|c|c|c|c|c|c|c|}
\hline \multirow[b]{2}{*}{ Step } & \multirow[b]{2}{*}{ Predictor } & \multicolumn{2}{|c|}{$\begin{array}{c}\text { Belief, that } \\
\text { Wikipedia is } \\
\text { valuable }\end{array}$} & \multicolumn{2}{|c|}{$\begin{array}{l}\text { Belief, that } \\
\text { Wikipedia is } \\
\text { detrimental }\end{array}$} & \multicolumn{2}{|c|}{$\begin{array}{c}\text { Belief, that } \\
\text { Wikipedia is } \\
\text { biased }\end{array}$} \\
\hline & & 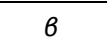 & $\Delta R^{2}$ & $B$ & $\Delta R^{2}$ & $B$ & $\Delta R^{2}$ \\
\hline \multirow[t]{2}{*}{1} & Age & -0.14 & 0.025 & 0.02 & 0.002 & 0.06 & 0.018 \\
\hline & $\operatorname{Sex}^{a}$ & 0.06 & & -0.04 & & 0.13 & \\
\hline \multirow[t]{7}{*}{2} & Age & $-0.16^{*}$ & 0.025 & 0.04 & 0.008 & 0.09 & 0.017 \\
\hline & $\operatorname{Sex}^{a}$ & 0.05 & & -0.03 & & 0.16 & \\
\hline & Extraversion & 0.06 & & 0.02 & & 0.04 & \\
\hline & Agreeableness & 0.11 & & -0.03 & & -0.09 & \\
\hline & Conscientiousness & -0.09 & & -0.02 & & 0.09 & \\
\hline & $\begin{array}{l}\text { Emotional } \\
\text { stability }\end{array}$ & -0.08 & & -0.07 & & -0.02 & \\
\hline & $\begin{array}{l}\text { Openness to } \\
\text { experience }\end{array}$ & 0.03 & & -0.02 & & -0.04 & \\
\hline \multirow[t]{9}{*}{3} & Age & $-0.16^{*}$ & 0.002 & 0.04 & 0.001 & 0.10 & 0.002 \\
\hline & $\operatorname{Sex}^{\mathrm{a}}$ & 0.06 & & -0.03 & & 0.15 & \\
\hline & Extraversion & 0.05 & & 0.03 & & 0.05 & \\
\hline & Agreeableness & 0.10 & & -0.03 & & -0.09 & \\
\hline & Conscientiousness & -0.09 & & -0.02 & & 0.09 & \\
\hline & $\begin{array}{l}\text { Emotional } \\
\text { stability }\end{array}$ & -0.09 & & -0.07 & & -0.01 & \\
\hline & $\begin{array}{l}\text { Openness to } \\
\text { experience }\end{array}$ & 0.03 & & -0.02 & & -0.04 & \\
\hline & Cynical hostility & -0.05 & & 0.03 & & 0.05 & \\
\hline & Total $R^{2}$ & & 0.052 & & 0.010 & & 0.038 \\
\hline
\end{tabular}

${ }^{\mathrm{a}} 0=$ women, $1=$ men

$* p<0.05 ; * * p<0.01$.

The regression analysis for belief that Wikipedia is valuable showed that the independent variables added in step 1 explained $1.8 \%$ of the variance $\left(F_{2,178}=1.67, p=0.19\right)$. The independent variables added in step 2 explained additional $1.7 \%$ of the variance $\left(F_{5,173}=0.61, p=0.69\right)$. The independent variables added in step 3 explained additional $0.2 \%$ of the variance $\left(F_{1,172}=0.45, p=0.51\right)$. The independent variables explained a total of $3.8 \%$ of the variance $\left(F_{8,172}=0.85, p=\right.$ 0.56 ). There were no significant variables added in step 3 (Tab. IV).

\section{CONCLUSIONS}

Hypothesis 1 was not confirmed. Agreeableness, emotional stability, openness to experience and cynical hostility were not related to editing articles on Wikipedia. Conscientiousness was negatively related to editing articles on Wikipedia. This negative relationship may emerge from preference of order and 
harmony which are hard to achieve in Wikipedia, as the website may seem to be edited in disorderly fashion.

Hypothesis 2 was not confirmed. Cynical hostility was not related to any specific - neither positive, nor negative opinions on Wikipedia. Cynical hostility was not related to trust in Wikipedia. Cynicism is connected with believe that people are driven by egoistic motives and they are the source of injustice in the world. In that regard, cynically hostile individuals should - by definition - be more critical and distrustful towards projects such as Wikipedia - created by voluntaries, non-profit and gratuitously developed. However, this study has shown that cynical hostility is not related to any of attitudes towards Wikipedia. This result may be due to cynically hostile individuals treating Wikipedia as knowledge source without linking it to people making articles. This interesting outcome should be investigated in future studies.

Hypothesis 3 was not confirmed. Extraversion was positively related to opinion I believe that Wikipedia is valuable, needed, but this correlation was very weak and other positive opinions were not related to extraversion. Openness to experience was positively related to opinions that For the most part the contents of Wikipedia are reliable. On the other hand openness to experience was positively related to opinion that There is a lot of misinformation in Wikipedia, while other positive opinions were not related to openness to experience. Large number of stimuli supplied both by reading and cocreating Wikipedia seem to be essential in relations between those two personality traits and positive opinions about Wikipedia. Nevertheless, Selwyn and Gorard [1] showed that those people are using Wikipedia as a bridge to other sources of knowledge. There was no relationship of extraversion and openness to experience with trust in Wikipedia. Agreeableness was not related to attitudes to Wikipedia or trust in it. It may be that this trait is more related to direct human interactions than to information on the web provided by other people. More generally, it may be that trust in online open resources is not related to any of the personality traits but rather to cognitive abilities and direct rational judgement of the content independently of any emotional or attitudinal inclinations.

Hypothesis 4 was partially confirmed. Conscientiousness was not related to trust in Wikipedia. On the other hand, conscientiousness was negatively related to opinions I believe that Wikipedia is valuable, needed and Young people can expand their horizons and gain new knowledge through Wikipedia. Other opinions - neither positive, nor negative were not related to conscientiousness. Negative relationship with conscientiousness may emerge from preference for more in-depth and systematic study of the resources. For more conscientious individuals Wikipedia may seem oversimplified and biased. Moreover, conscientious students may be more prone to teachers advises not to use Wikipedia as it is not a reliable source.

It is necessary to understand the relationship between personality traits and knowledge sharing. Previous study investigating this relationship was conducted in a company [17]. Companies are characterized by organized work and face to face contacts which are not present in the case of Wikipedia or other open educational resources. Research conducted by
Bargh, McKenna and Fitzsimons [23] showed that people interact differently with each other in face to face interactions than those which take place in Internet chat. These results suggest that anonymity provided by the Internet can somehow influence relationship between personality traits and opinions about Wikipedia.

As far as the Authors are aware, the present study is the first to investigate the relationship of five factor model personality traits and cynical hostility with opinions about, attitude to and trust in Wikipedia among university students. Valid and reliable measures were used in the study. Regarding the limitations, the sample was fairly small, predominantly female and not representative which limits the possibility of generalizing conclusions to the whole population of students in Poland. Furthermore, all data in the present study were based on self-report which increases the risk of common method bias. Future studies should overcome these limitations.

\section{REFERENCES}

[1] N. Selwyn, S. Gorard, Students' use of Wikipedia as an academic resource - Patterns of use and perceptions of usefulness. "The Internet and Higher Education" (28) 2016, pp. 28-34.

[2] K. Grodecka, K. Śliwowski, Przewodnik po Otwartych Zasobach Edukacyjnych (wersja 4. zaktualizowana). Koalicja Otwartej Edukacji, 2012.

[3] UNESCO, World Open Educational Resources (OER) Congress, 2012. Available at: http://www.unesco.org/

[4] S. Lim, N. Kwon, Gender differences in information behavior concerning Wikipedia, an unorthodox information source? "Library \& Information Science Research" 32(3) 2010, pp. 212-220.

[5] A. J. Head, M. B. Eisenberg, How today's college students use Wikipedia for course-related research. "First Monday. Peer-reviewed Journal on the Internet" 15(3) 2010. Available at: http://firstmonday.org/.

[6] A. Sawicki, B. Atroszko, P. Atroszko, "Uwarunkowania i potencjalne konsekwencje cynicznej wrogości w perspektywie edukacyjnej”. In A. Nawrocka, F. Makurat \& R. Breska (Eds.), Psychospołeczne aspekty zdrowia, Sopot: Wydawnictwo Athenae Gedanenses, pp. 51-68, 2016.

[7] T. W. Smith, K. Glazer, J. M. Ruiz, \& L. C. Gallo, Hostility, anger, aggressiveness, and coronary heart disease: an interpersonal perspective on personality, emotion, and health. "Journal of personality" 72(6) 2004, pp. $1217-1270$.

[8] M. Sęktas, A. J. Sawicki, L. A. Pianka, \& P. A. Atroszko, Relationship between cynical hostility and values from educational perspective preliminary research. In: J. Leśny, J. Nyćkowiak (Eds.), "Badania i Rozwój Młodych Naukowców w Polsce. Nauki humanistyczne i społeczne”, Poznań: Młodzi Naukowcy, pp. 98-104, 2016.

[9] L. Sendal, A. Sawicki, P. Bagińska, \& P. Atroszko, Relationship of cynical hostility with anxiety and depressiveness among university students in Poland. In J. Leśny, J. Nyćkowiak (Eds.), "Badania i Rozwój Młodych Naukowców w Polsce. Nauki humanistyczne i społeczne", Poznań: Młodzi Naukowcy, pp. 91-98, 2016.

[10] L. Sendal, P. Krzyżaniak, A. Raczyńska, \& P. Atroszko, The mediating effect of coping strategies on cynical hostility and perceived stress preliminary findings. In J. Leśny, J. Nyćkowiak (Eds.), Badania i Rozwój Młodych Naukowców w Polsce. Nauki humanistyczne i społeczne, Poznań: Młodzi Naukowcy, pp. 83-91, 2016.

[11] P. T. Costa Jr, R. R. McCrae, Revised NEO Personality Inventory (NEO-PI-R) and NEO Five-Factor Inventory (NEO-FFI) manual. Odessa, FL: Psychological Assessment Resources, 1992.

[12] A. Vedel, The Big Five and tertiary academic performance: A systematic review and meta-analysis. "Personality and Individual Differences" (71) 2014, pp. 66-76. 
[13] T. L. Giluk, Mindfulness, Big Five personality, and affect: A metaanalysis. "Personality and Individual Differences" 47(8) 2009, pp. 805811.

[14] R. Kotov, W. Gamez, E. Schmidt, \& D. Watson, Linking "big" personality traits to anxiety, depressive, and substance use disorders: a meta-analysis. "Psychological Bulletin" 136(5) 2010, pp. 768-821.

[15] S. Trapmann, B. Hell, J. O. W. Hirn, \& H. Schuler, Meta-Analysis of the Relationship Between the Big Five and Academic Success at University. "Journal of Psychology" (215) 2007, pp. 132-151.

[16] M. R. Barrick, M. K. Mount, The Big Five personality dimensions and job performance: meta-analysis. "Personnel Psychology" 44(1) 1991, pp. 1-26.

[17] K. Matzler, B. Renzl, J. Müller, S. Herting, \& T. A. Mooradian, Personality traits and knowledge sharing. "Journal of Economic Psychology" (29) 2008, pp. 301-313.

[18] B. Atroszko, Do young people trust Wikipedia? In S. Brown, S. Larsen, K. Marrongelle, \& M. Oehrtman (Eds.), "The 4th Electronic International Interdisciplinary Conference", Zilina: EDIS - Publishing Institution of the University of Zilina, pp. 109-114, 2015.
[19] R. N. Landers, J. W. Lounsbury, An investigation of Big Five and narrow personality traits in relation to Internet usage. "Computers in Human Behavior" 22(2) 2004, pp. 283-293.

[20] S. D. Gosling, P. J. Rentfrow, W. B. Swann Jr., A Very Brief Measure of the Big Five Personality Domains. "Journal of Research in Personality" (37) 2003, pp. 504-528.

[21] A. Sorokowska, A. Słowińska, A. Zbieg, \& P. Sorokowski,, Polska adaptacja testu Ten Item Personality Inventory (TIPI) - TIPI-PL wersja standardowa i internetowa, Wrocław: WrocLab, 2014.

[22] W. W. Cook, D. M. Medley, Proposed hostility and pharisaic-virtue scales for the MMPI. "Journal of Applied Psychology" 38(6) 1954, pp. 414-418.

[23] P. Clarke, G. Fisher, J. House, J. Smith, D. Weir, Guide to Content of the HRS Psychosocial Leave-Behind Participant Lifestyle Questionnaires: 2004-2006. Survey Research Center, Institute for Social Research; Ann Arbor, University of Michigan, 2008. 